\title{
Aspergillus flavus Exploits Maize Kernels Using an "Orphan" Secondary Metabolite Cluster
}

\author{
Ludovica Antiga ${ }^{1,+}$, Sonia Roberta La Starza ${ }^{1,+}$, Cecilia Miccoli ${ }^{2,+}$, Simone D'Angeli ${ }^{1}$, \\ Valeria Scala ${ }^{3}{ }^{\circledR}$, Marco Zaccaria ${ }^{4}$, Xiaomei Shu ${ }^{5}$, Gregory Obrian ${ }^{6}$, Marzia Beccaccioli ${ }^{1, *(D)}$, \\ Gary A. Payne ${ }^{6}$ and Massimo Reverberi ${ }^{1}$ (D) \\ 1 Department of Environmental Biology, Sapienza University of Rome, P.le Aldo Moro 5, 00185 Roma, Italy; \\ ludovicaantiga@gmail.com (L.A.); lastarza.soniaroberta@gmail.com (S.R.L.S.); \\ simone.dangeli@uniroma1.it (S.D.); massimo.reverberi@uniroma1.it (M.R.) \\ CREA-OFA, Via di Fioranello 52, 00134 Rome, Italy; cecilia.miccoli@crea.gov.it \\ CREA-DC, via C.G. Bertero 22, 00156 Roma, Italy; valeria.scala@crea.gov.it \\ 4 Department of Biology, Boston College, 140 Commonwealth avenue, Chestnut Hill, MA 02467, USA; \\ zaccarim@bc.edu \\ 5 Center for Biotechnology and Genomics, Texas Tech University, 2500 Broadway, Lubbock, TX 79410, USA; \\ shuxiaomei@gmail.com \\ 6 Department of Plant Pathology, North Carolina State University, Raleigh, CA 27607, USA; \\ gregoryobrian@gmail.com (G.O.); gary.a.payne@gmail.com (G.A.P.) \\ * Correspondence: marzia.beccaccioli@uniroma1.it \\ + These authors contributed equally to this work.
}

Received: 22 September 2020; Accepted: 30 October 2020; Published: 3 November 2020

check for updates

\begin{abstract}
Aspergillus flavus is a saprophytic cosmopolitan fungus, capable of infecting crops both preand post-harvest and exploiting different secondary metabolites, including aflatoxins. Aflatoxins are known carcinogens to animals and humans, but display no clear effect in host plants such as maize. In a previous study, we mined the genome of $A$. flavus to identify secondary metabolite clusters putatively involving the pathogenesis process in maize. We now focus on cluster 32, encoding for fungal effectors such as salicylate hydroxylase $(\mathrm{SalOH})$, and necrosis- and ethylene-inducing proteins (npp1 domain protein) whose expression is triggered upon kernel contact. In order to understand the role of this genetic cluster in maize kernel infection, mutants of $A$. flavus, impaired or enhanced in specific functions (e.g., cluster 32 overexpression), were studied for their ability to cause disease. Within this frame, we conducted histological and histochemical experiments to verify the expression of specific genes within the cluster (e.g., SalOH, npp1), the production of salicylate, and the presence of its dehydroxylated form. Results suggest that the initial phase of fungal infection ( 2 days) of the living tissues of maize kernels (e.g., aleuron) coincides with a significant increase of fungal effectors such as $\mathrm{SalOH}$ and $\mathrm{Npp} 1$ that appear to be instrumental in eluding host defences and colonising the starch-enriched tissues, and therefore suggest a role of cluster 32 to the onset of infection.
\end{abstract}

Keywords: Aspergillus flavus; maize kernel; salicylate hydroxylase; npp1; effectors; quercetin; histology

\section{Introduction}

Aspergillus is one of the best-described fungal genera, mainly because of its negative impact on economy and agriculture through production of highly toxic secondary metabolites [1]. Aspergillus flavus is studied for its role in producing aflatoxins (AFs), the most carcinogenic natural substances currently detected in food. A. flavus is more virulent than most Aspergillus species; furthermore, A. flavus causes a broad spectrum of disease in humans ranging from cutaneous to central nervous system infections [2]. 
A. flavus is a nutrient recycler abundant in the soil [2], which often opportunistically infects staple crops, such as maize and leads to aflatoxin contamination [3-6]. Maize (Zea mays L.) is one of the major crops susceptible to A. flavus infection and subsequent aflatoxin contamination [7]. One of the earliest reports of infection on maize by Aspergillus was in Texas in 1920. Aflatoxins contamination of maize was thought to be a post-harvest consequence of improper storage. However, research has indicated that Aspergillus infection may occur pre-harvest [8]. In the last years, contamination levels in Europe have exceeded the threshold allowed by EFSA [9] for commerce. Improvement strategies have thus been necessary, e.g., dilution of the contaminated commodities with safer grain, or chemical treatment to destroy or inactivate aflatoxins $[10,11]$. Maize kernels are generally susceptible to infection by A. flavus, yet aflatoxin production in corn is extremely variable due, in part, to its sporadic occurrence among ears and kernels. The fungal structures associated with aflatoxins (e.g., conidial heads and sclerotia) likely exhibit a similar sporadic distribution pattern between maize ear and kernel [3]. Over recent years, in the U.S., A. flavus infection caused 100s of millions USD of yearly losses due to aflatoxin contaminated crops [12]. The studies on maize- $A$. flavus interaction have revealed that additive and dominant gene actions are important for resistance to aflatoxin production. Diallel mating designs were employed to study the inheritance of resistance to both A. flavus ear rot and aflatoxin accumulation. These studies have reported that general combining ability had a greater effect on the aflatoxin resistance in maize than specific combining ability, suggesting that additive gene effect is more important than dominant gene effect. Transgenic approaches have been attempted to manage A. flavus infection and improve food safety [13].

Secondary metabolites (SM) play an important role in fungal ecology as fitness factors, but they are, by definition, not essential for growth or survival. SMs are structurally heterogeneous and their coding sequences are organized in clusters, each cluster containing enzymatic genes and often transcriptional factors $[1,14]$. In A. flavus, SMURF (Secondary Metabolite Unknown Regions Finderavailable at http://www.jcvi.org/smurf) predicted at least 56 different clusters for production of secondary metabolites [15], which can be divided in four clades based on hierarchical clustering. Following this from the division in clades, and the work by Georgianna et al. [16] in which connections between ecological conditions and gene expression were first shown, Reverberi et al. [17] examined genotypic and phenotypic changes in A. flavus during its growth and invasion of maize kernels: out of 56 secondary metabolites clusters, 24 were differentially expressed. Among the secondary metabolites up-regulated during maize kernel infection, cluster 32 emerged as the most interesting since it had not been previously implicated in pathogenicity. At least two genes within cluster 32, DMATS and GGPS, are implied in the biosynthesis of aflatrem, a tremorgenic mycotoxin causing neurological disorders [17-19]. Intriguingly, in this study we found that a set of genes within cluster 32 co-expressed with the necrosis- and ethylene-inducing peptide (npp1), which belongs to the Nep1-Like Proteins (NLPs), a family of non-host-specific elicitors causing necrosis and activating defence responses in dicotyledonous plants [20,21]. NLPs are small phytotoxic conserved proteins able to induce hypersensitive response (HR)-like cell death, reactive oxygen species (ROS) and ethylene production. Recent structural analyses indicate that NLPs are similar to virulence- promoting cytolytic toxins and act by interfering with integrity of the plasma membrane; the activation of host defences starts with the disruption of plasma membrane [22].

Current approaches are insufficient to control pre-harvest colonisation of crops by A. flavus and subsequent AF contamination. Genetic strategies could enable the development of new methodologies to control the pathogen and, consequently, AF biosynthesis. To this end, it is important to gain insight into the genetic regulatory pathways that control A. flavus morphogenesis and toxin biosynthesis [23].

We focused our attention on the transcriptional regulation of cluster 32, which we define a "orphan" cluster since its function is hitherto unknown. For the sake of clarity, we aim at defining cluster 32 within this work. Previous bioinformatic analysis indicated that a putative actor in this process could be the AFLA_096370 gene encoding for a DNA-binding zinc protein, $\mathrm{Zn}_{2} \mathrm{Cys}_{6}$, transcriptional factor. The fungal $\mathrm{C}_{6}$ zinc-finger cluster proteins are normally associated with the regulation of 
different functions including carbon and nitrogen utilization, production of secondary metabolites, and asexual and sexual development [24]. In this study, we analysed the behaviour of an A. flavus strain overexpressing AFLA_096370 as well as both knocked-out and over-expressing NepA, a necrosis and ethylene-inducing peptide, to assess the role of cluster 32 in the pathogenic process of $A$. flavus on maize kernels.

\section{Results \& Discussions}

\subsection{Phenotypic Characterization of A. flavus Mutant Strain}

Our first approach was to characterize the morphology of the strains by visual observation. AF3357 (wild type) and AFC-1, a mutant $(-p y r G,-\arg D)$ auxotroph for uracil and arginine, had similar total growth, but AF3357 grew faster and produced more conidia. $\mathrm{Zn}_{2} \mathrm{Cys}_{6}-\mathrm{OE}-\mathrm{GFP}$ mutant, which overexpresses the transcription factor, showed hampered growth but strong conidiation. The knockout for the transcription factor, $\mathrm{Zn}_{2} \mathrm{Cys}_{6} \Delta$, displayed faster growth but weaker conidiation. All the evaluations were made 7 days after plating (Figure S1).

\subsection{Colonisation of Maize Kernels by A. flavus AF3357, AFC-1 and $\mathrm{Zn}_{2} \mathrm{Cys}_{6}-\mathrm{OE}-\mathrm{GFP}$}

Colonisation of maize kernels was observed for several strains by in vitro infection assay (Figure S2); histological sections were observed with an optical microscope. At 2 days after infection (dai), AF3357 had completely colonised the pericarp and produced a visible mycelial mat (Figure 1b); at 3 dai, conidia were present in the aleurone layer and within the pericarp (Figure 1f); and at 4 dai, every cell of the aleuronic layer had been invaded completely (Figure 1j). Regarding AFC-1 and $\mathrm{Zn}_{2} \mathrm{Cys}_{6}-\mathrm{OE}-\mathrm{GFP}$ strains, no sign of fungal contamination appeared (conidia or mycelial mat) within the kernels at 2 dai (Figure 1c,d). In the sole $\mathrm{Zn}_{2} \mathrm{Cys}_{6}-\mathrm{OE}$-GFP mutant, the pericarp and the aleuronic layer, but not the embryo, were invaded at 3 dai (Figure $1 \mathrm{~h}$ ); at 4 dai, AFC- 1 behaved similarly to $\mathrm{Zn}_{2} \mathrm{Cys}_{6}$-OE-GFP in that a dense mycelial mat was visible between the pericarp and the aleuronic layer (Figure 1k). Notwithstanding the difference in the rate of invasion among the three strains, the aleuronic layer might represent a barrier to early-stage infection (Figure 1f,j,l), but as the disease progresses the kernel eventually collapse (at 7 dai, data not shown due to kernels high deterioration). The $\mathrm{Zn}_{2} \mathrm{Cys}{ }_{6} \Delta$ strain showed low potential for maize kernels invasion, because at 7 dai, no signs of infection could be observed except for a minimal growth on the external surface of the kernel (Figure S3).

Post-infection programmed cell death (PCD) occurred in the aleuronic layer at different dai among the strains (AF3357 < $\mathrm{Zn}_{2} \mathrm{Cys}_{6}-\mathrm{OE}-\mathrm{GFP}<\mathrm{AFC}-1$ ), (Figure 1f,h,k). The timing of PCD occurrences is better highlighted with the TUNEL assay (Figure 2) where blue nuclei, indicative of PCD onset, are brighter in AF3357-infected kernels than in the other samples. We also report decreased PCD in $\mathrm{Zn}_{2} \mathrm{Cys}_{6} \Delta$ - infected kernels through TUNEL assay (Figure S4).

Comparison with viable aleuronic cells revealed vacuolization in the PCD-affected cells starting from 2 dai (Figure $1 \mathrm{~b}-\mathrm{d}, \mathrm{f}-\mathrm{h}, \mathrm{j}-\mathrm{l}$ ); moreover, the protein storage vacuoles disappeared in the PCD-affected cells, whereas the viable cells were filled with these vacuoles (arrow in Figure 1a). Vacuoles were similar to the vesicles preceding PCD in the aerenchyma formation in maize and may be interpreted as lytic vacuoles [25]. 


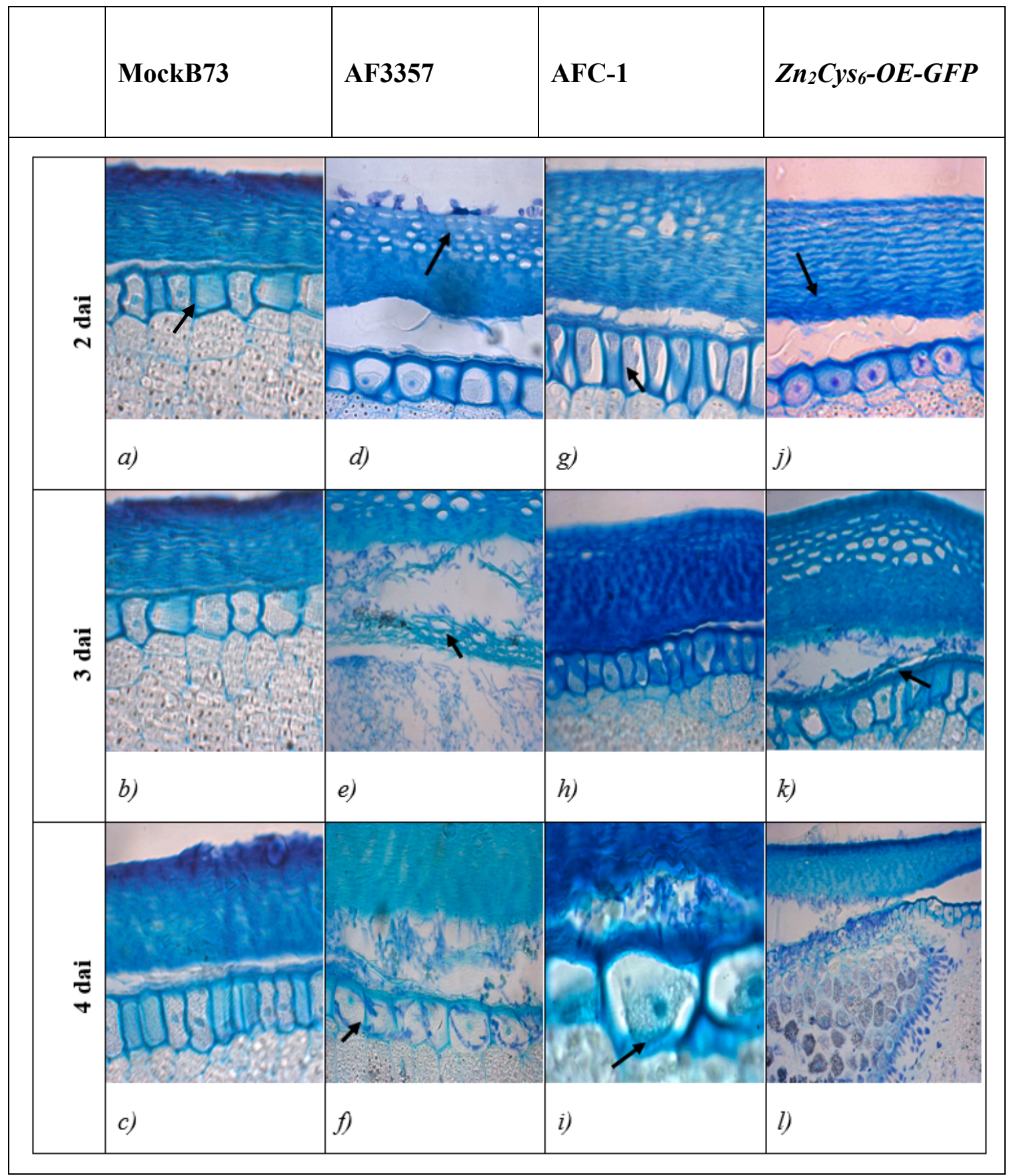

Figure 1. Histological assays showing the progression of the infection by different strains at 2, 3 and 4 dai. MockB73 (a-c) tissues were not infected at any time point. Wild-type AF3357 (d-f) spores are present just outside the kernel at 2 dai (d), and at 4 dai the fungus had directly invaded the aleuronic cells as shown by the arrow (f). Starting at 2 dai, the AFC- 1 mutant $(\mathbf{g}-\mathbf{i})$ experienced visible vacuolisation of aleuronic cells (arrows in $\mathbf{g}$ ) as symptoms of PCD onset, progressing to 4 dai with ongoing infection (i). The transcription factor overexpressing mutant, $\mathrm{Zn}_{2} \mathrm{Cys}_{6}-\mathrm{OE}-\mathrm{GFP}(\mathbf{j}-\mathbf{l})$, as a consequence of fungal invasion caused detachment of the periderm from the aleuronic layer (arrow in $\mathbf{j}$ ), then proceeds just outside the aleuronic layer (arrow in k) until the kernel is collapsed (1). Magnification 400×. 


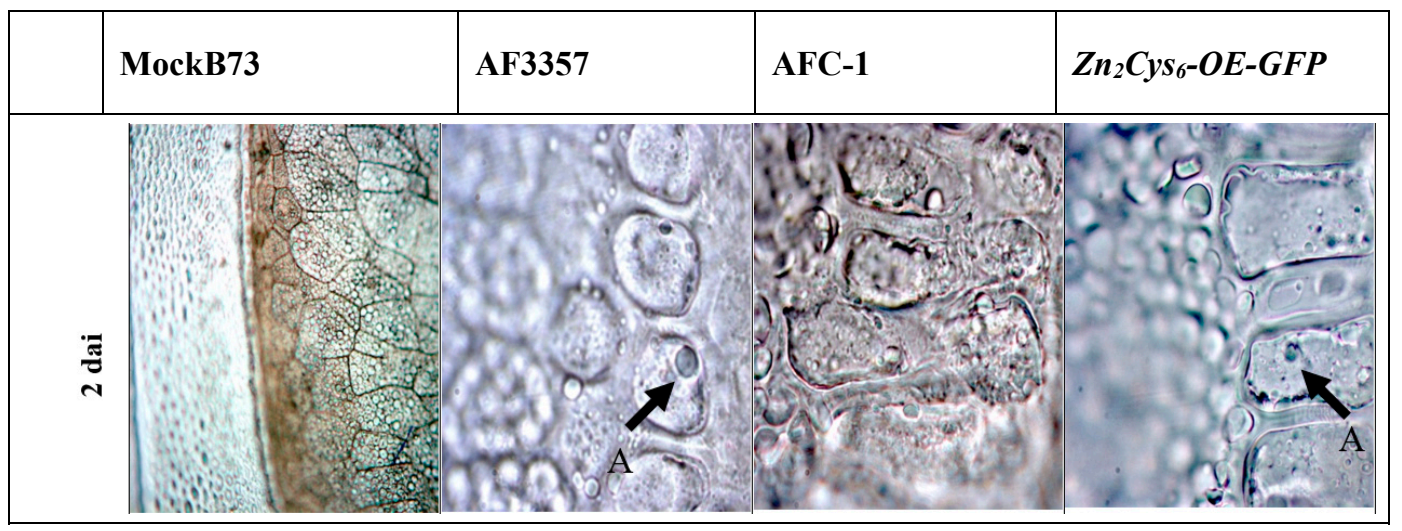

Figure 2. TUNEL assay at 2 dai in all the studied strains: MockB73, AF3357 (wild type); AFC-1 (-pyrG, $-\operatorname{argD}$ mutant); $\mathrm{Zn}_{2} \mathrm{Cys}_{6}-\mathrm{OE}-\mathrm{GFP}$ (overexpressing the transcription factor). In all three cases, the cells belong to the aleuronic layer. This assay shows apoptotic (A) nuclei in blue indicated by the arrows. Magnification 1000x.

\subsection{Expression of Genes Related to the Pathogenesis}

Salicylic acid (SA) signalling pathways play an important role in plant defence [26]. To counteract the effect of SA synthesis by the plant, some pathogens (e.g., hemi-biotrophic ones) can degrade it. These pathogens, which include a number of fungal species, can convert SA to catechol and/or gentisate, directly or through intermediates [27]. This reaction is accomplished by a specific enzyme known as salicylate hydroxylase. In Arabidopsis, SA induction-deficient mutants, inactivated for the isochorismate synthase gene, fail to synthesize SA in response to pathogen infection, resulting in enhanced susceptibility to bacterial and fungal pathogens [28]. Thus, hemi-biotrophic pathogens often jeopardize the SA pathway to delay PCD, especially during the biotrophic stage. Indeed, in the later, necrotrophic stage, these pathogens prompt cell death [29]. Regarding this aspect, Npp1 is a necrosisand ethylene-inducing peptide domain present in all NLPs. It has been proposed to have a dual function in plant-pathogen interactions, acting both as a trigger of immune response and as a toxin-like virulence factor [30]. NLPs are relatively small proteins of about $24 \mathrm{kDa}$ that exhibit a high degree of similarity at amino acid sequence level, including the presence of two highly conserved cysteine residues that form an intramolecular disulfide bridge essential for NLP activities, and also a central hepta-peptide motif "GHRHDWE" that is part of the negatively charged cavity exposed at the protein surface. Both are necessary for plasma membrane permeabilization and cytolysis in plant cells [31]. Plants produce phenolic compounds for pigmentation, growth, and reproduction even under stressors such as wounding, drought, and pathogen attack [32]. The latter can deeply affect the synthesis and accumulation of phenolics by rutin and quercetin, amongst the main phenolic antioxidant compounds in plants [33]. It is largely accepted that oxidative stress plays an important role as an early factor in establishing the fate of pathogen/plant interactions. In relation to this, host cells have based an important part of their defence toolkit on antioxidant activities, which are triggered soon after pathogen infection [34]. It appears crucial for the fungal pathogen to disable this type of defence to achieve tissue colonisation.

Following up on our previous work in which we reported a correlation between cluster 32 and the pathogenicity process of $A$. flavus in maize [17], we focused our attention in this study on three genes inside this cluster: salicylate hydroxylase $(\mathrm{SalOH})$, the gene responsible for necrosis- and ethylene-inducing protein (npp1), and quercetin dehydrogenase (AFLA_096260).

Gene expression was monitored in A. flavus AF3357, in the mutant strains $\mathrm{Zn}_{2} \mathrm{Cys}_{6}-\mathrm{OE}-\mathrm{GFP}$ and in AFC-1, starting at $14 \mathrm{~h}$ through to 5 dai (Figure 3). Time intervals were chosen based on the effects of the fungal invasion observed during the histological analysis (Figure 1). In AF3357, SalOH is expressed just $14 \mathrm{~h}$ after inoculation as a sign of early infection and it follow a constant trend until 5 dai. The same expression pattern was observed for npp 1 and AFLA_096260, from 1 to 4 dai. In strain $\mathrm{Zn}_{2} \mathrm{Cys}_{6}$-OE-GFP, 
$\mathrm{SalOH}$ had the clearest pattern, that is a constant overexpression as possibly expected. The other two genes instead present a more erratic, even if overxpresssed for some time points, trend; this suggests that other means of controlling the expression of these genes could occur. In AFC-1, SalOH and NPP1 expression levels reflect the fact that this strain is less virulent, as indicated also in Figure 1. Expression levels of the three genes in each strain were as follows: $\mathrm{Zn}_{2} \mathrm{Cys}_{6}-\mathrm{OE}-\mathrm{GFP}>\mathrm{AF} 3357>\mathrm{AFC}-1$, as shown in Figure 3. Notably, the three genes appeared to be equally important in supporting the pathogenic behaviour of $A$. flavus in maize kernels.

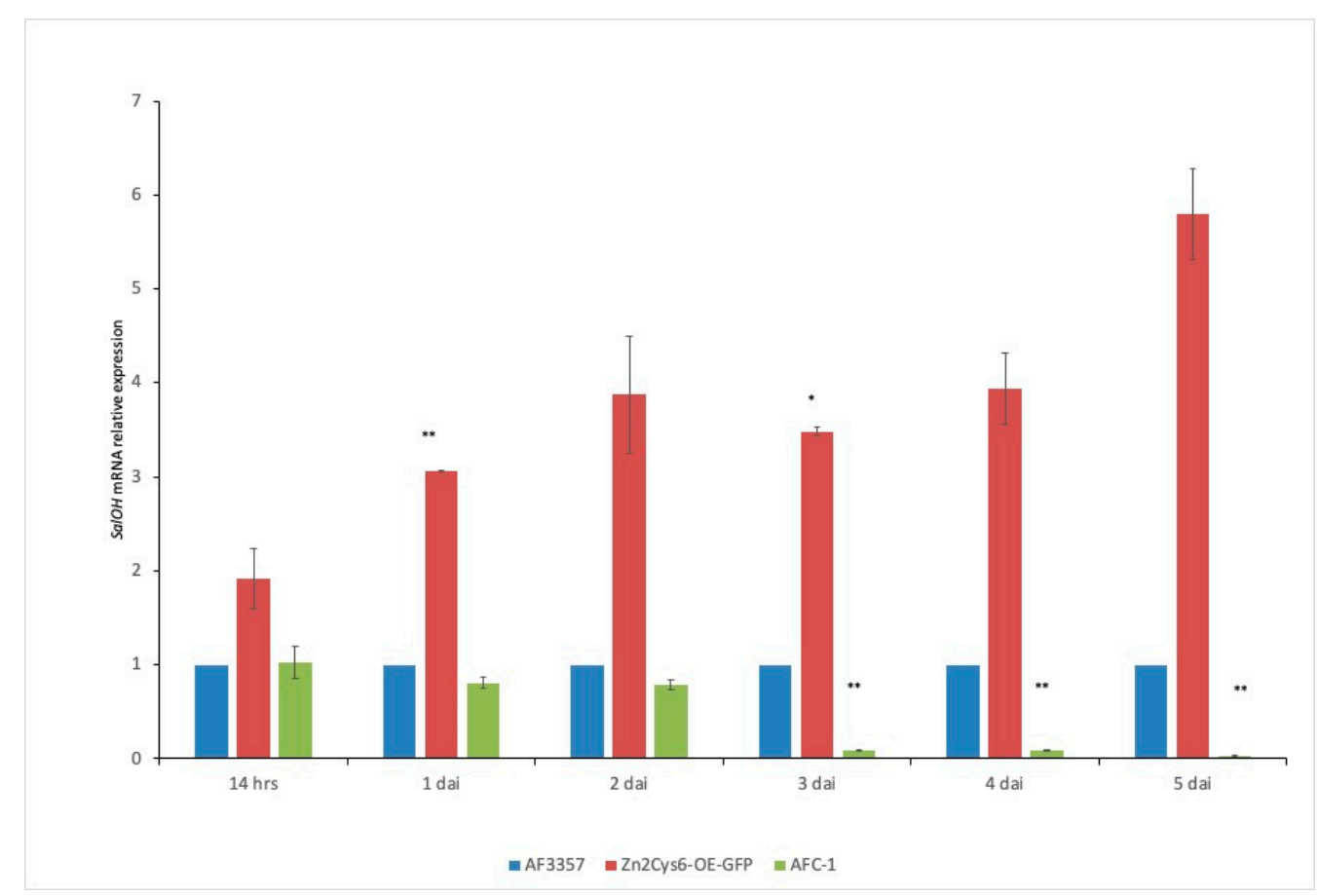

(a)

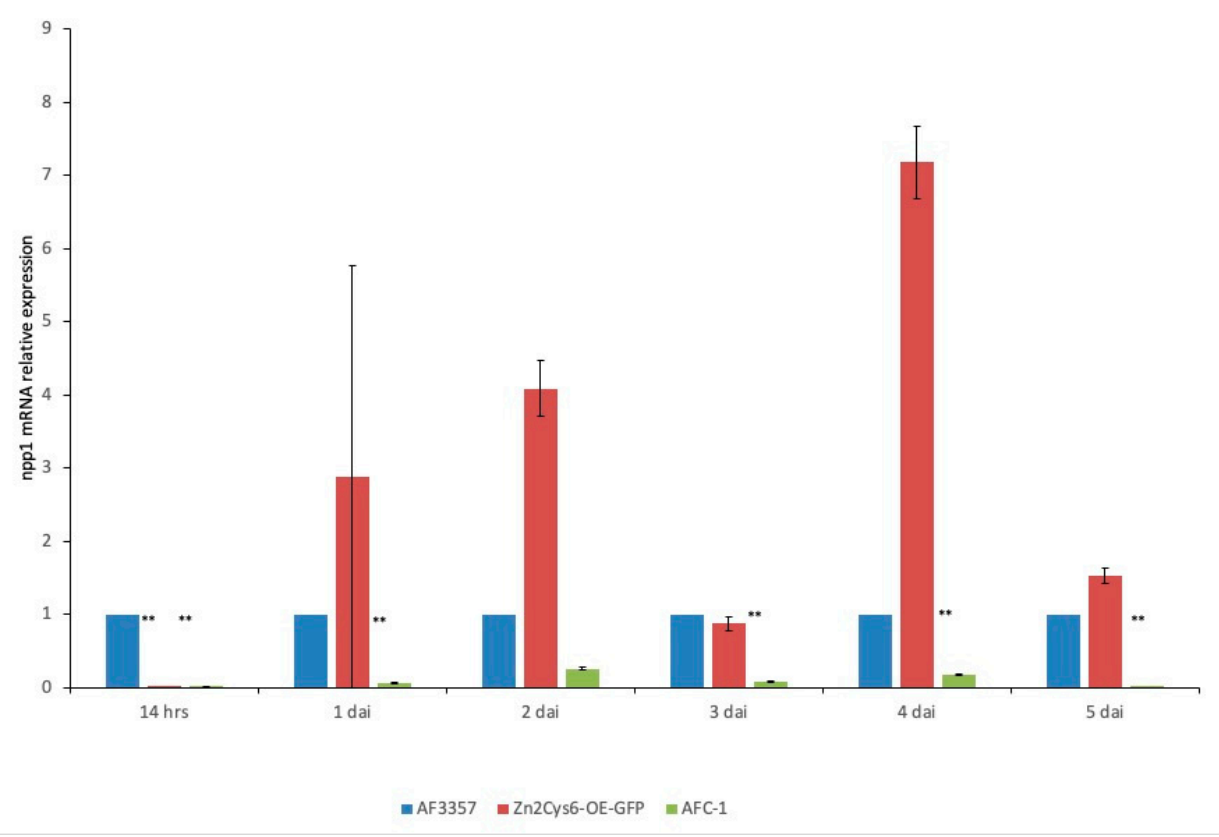

(b)

Figure 3. Cont. 


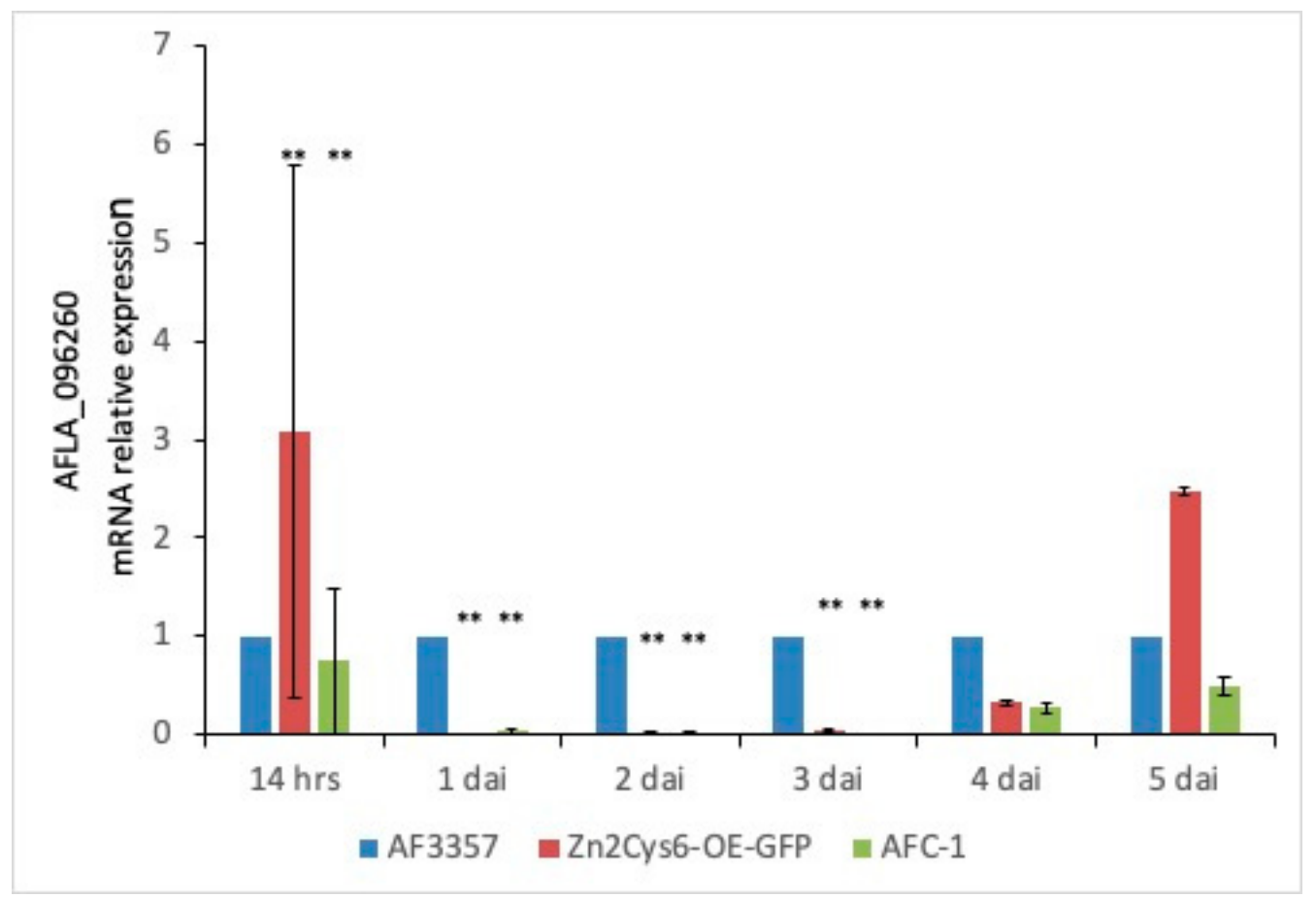

(c)

Figure 3. Relative expression of transcriptional levels for cluster 32 genes $\mathrm{SalOH}(\mathbf{a}), n p p 1$ (b) and AFLA_096260 (c) in fungal strains AF3357, $\mathrm{Zn}_{2} \mathrm{Cys}_{6}$-OE-GFP and AFC-1 from $14 \mathrm{hrs}$ to 5 dai. Mean values and standard deviations were used to perform $t$-tests comparing $\mathrm{Zn}_{2} \mathrm{Cys}_{6}$-OE-GFP or AFC- 1 to AF3357 $\left({ }^{*} p<0.05 ;{ }^{* *} p<0.01\right)$.

\subsection{SA and Cathecol Accumulation in Maize-Infected Kernel}

With the aim to verify the activity of fungal $\mathrm{SalOH}$ into maize kernels infected with several strains (AF3357, AFC-1, $\mathrm{Zn}_{2} \mathrm{Cys}_{6}-\mathrm{OE}-\mathrm{GFP}$ ), HPLC-MS/MS quantification of both salicylic acid and its by-product catechol was performed. As shown in Figure 4, the progression of SA and its conversion into catechol is related to fungal infection, particularly in the presence of AF3357, presumably in correlation to the expression of SalOH. An unexpected difference emerged among the strains: AF3357, the most aggressive in this comparison, is the better converter of SA into catechol (Figure 4). Relating this to the histological and gene expression assays, the ability to convert $\mathrm{SA}$ into catechol follows a similar path for the three fungal strains examined (AF3357 $>\mathrm{Zn}_{2} \mathrm{Cys}_{6}-\mathrm{OE}-\mathrm{GFP}>\mathrm{AFC}-1$ ). Nevertheless, the overall amount of conversion is up to $10-15 \%$ of the total SA produced by the kernels. The decreasing levels of SA are probably not sufficient to switch kernels' defences off; instead, the lower percentage of SA should be consistent with a slower reaction to A. flavus invasion. Since the resistance of maize to AF is essentially based on a multi-gene horizontal defence [35], slowing the reaction down could cause more damage than expected. In fact, both the infection with AF3357 and with $\mathrm{Zn}_{2} \mathrm{Cys}_{6}-\mathrm{OE}$-GFP prevented the kernel from germinating (as shown below). In fact, as reported by Nancy Keller [36] more than 25 years ago, following embryo germination, mycelial activity around the embryo ceases, probably as a consequence of antifungal compounds secretion. In our case, the pathogen succeeded in engaging in the invasion of the endosperm even by preventing embryo germination [37].

Also in this study, we tried to report the activity of quercetin dioxygenase encoded by the AFLA_096260 gene. Quercetin dioxygenase converts quercetin, itself a by-product of rutin, into protocatechuoyl-phloroglucinolcarboxylic acid (PPA). Our HPLC-MS/MS analysis was unable to identify this product in the maize kernels from each assayed treatment, even though the in vitro assay proved that AF3357 is able to convert rutin into quercetin [34], and quercetin into PPA (Table S5). It is probable that, even if this activity is important in maize kernel invasion, as indicated by gene expression results (Figure 3), the amount of PPA is below our instruments sensitivity threshold. 


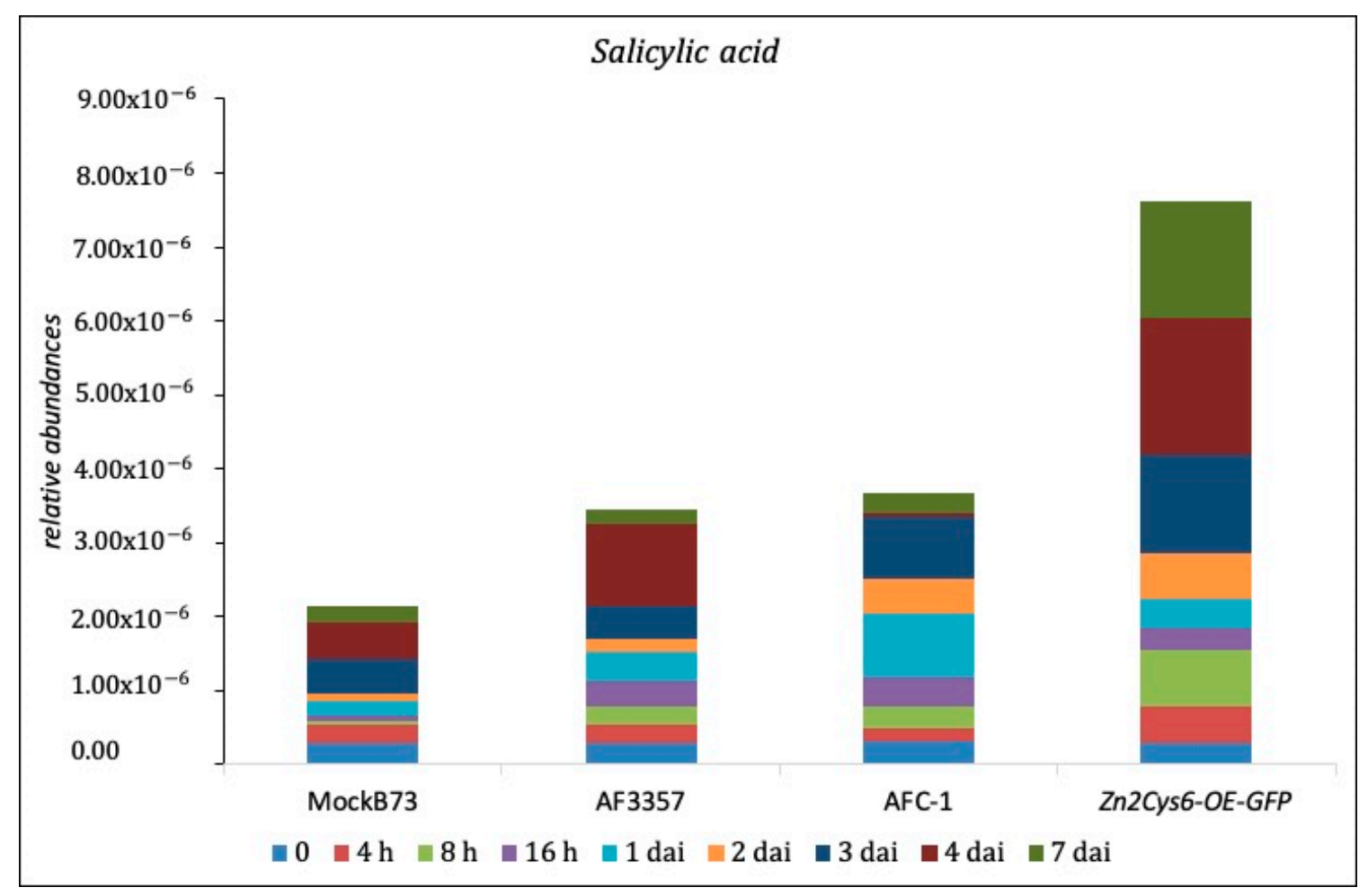

(a)

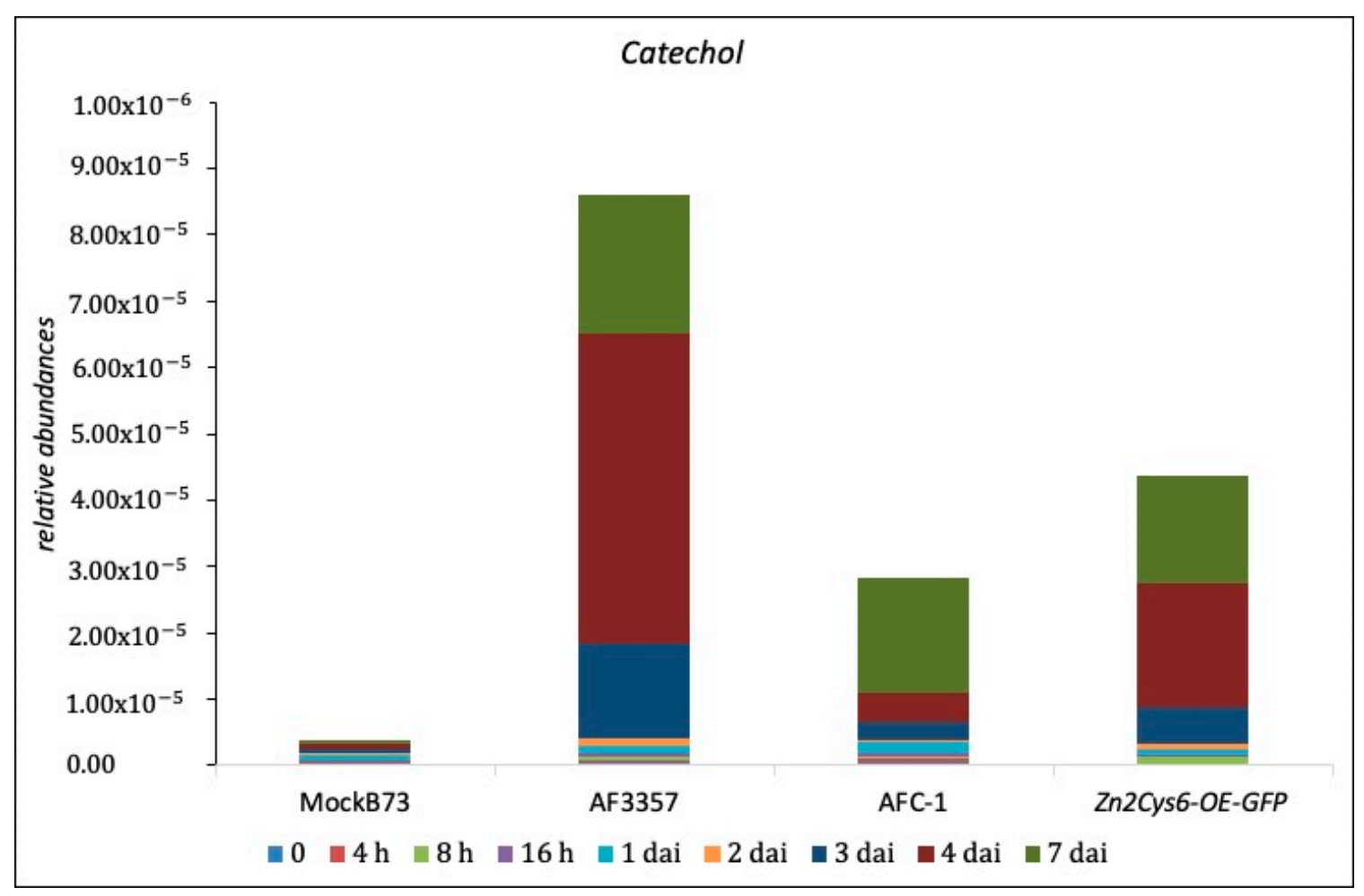

(b)

Figure 4. Relative abundances of salicylic acid (a) and catechol (b) detected in maize when not infected (MockB73) or infected with one of three A. flavus strains. The colours in each bar represent different infection time points. 


\subsection{Npp1 Induces Necrotic Cell Death}

To highlight the importance of $n p p 1$ in maize kernel invasion by A. flavus, two strains presenting the GUS reporter gene have been tested using a histochemical approach: nepA $A$-GUS B9-5 (npp1 knockout mutant) and nepA-OE-GUS B5-12 (npp1 overexpression mutant). In relation to previous results on both gene expression and hormonal analysis, we hypothesize that $A$. flavus biotrophically colonises the kernels in the first stage ( $0-2$ dai) and switches to necrotrophy at a later stage (3-7 dai). In support of this hypothesis, we observed an early expression (Figure 3) and enzymatic conversion of SA (Figure 4) related to $\mathrm{SalOH}$ activity. Thus, we should expect that the lack of expression of a necrosis factor such as $n p p 1$, or its overexpression, respectively lead to an anticipation or a delay of kernels colonisation. In fact, Npp1 is uninvolved in the biotrophic stage and acts to prompt the necrotrophic stage, when typical ear rot symptoms appear.

Figure 5 shows the nepAD-GUS B9-5 strain invading maize kernels or prior to the nepA-OE-GUS B5-12 strain (check images at 2 dai for comparison). According to this interpretation, the lack of npp1 should limit the ability of the nepAL-GUS B9-5 strain to colonise the kernels in the later stages (i.e., after 3-4 dai). In fact, the kernels remain viable (radicle emersion at 7 dai) in comparison to the kernels infected with the nepA-OE-GUS B5-12 strain that show clear symptoms of rot at 3-4 dai.

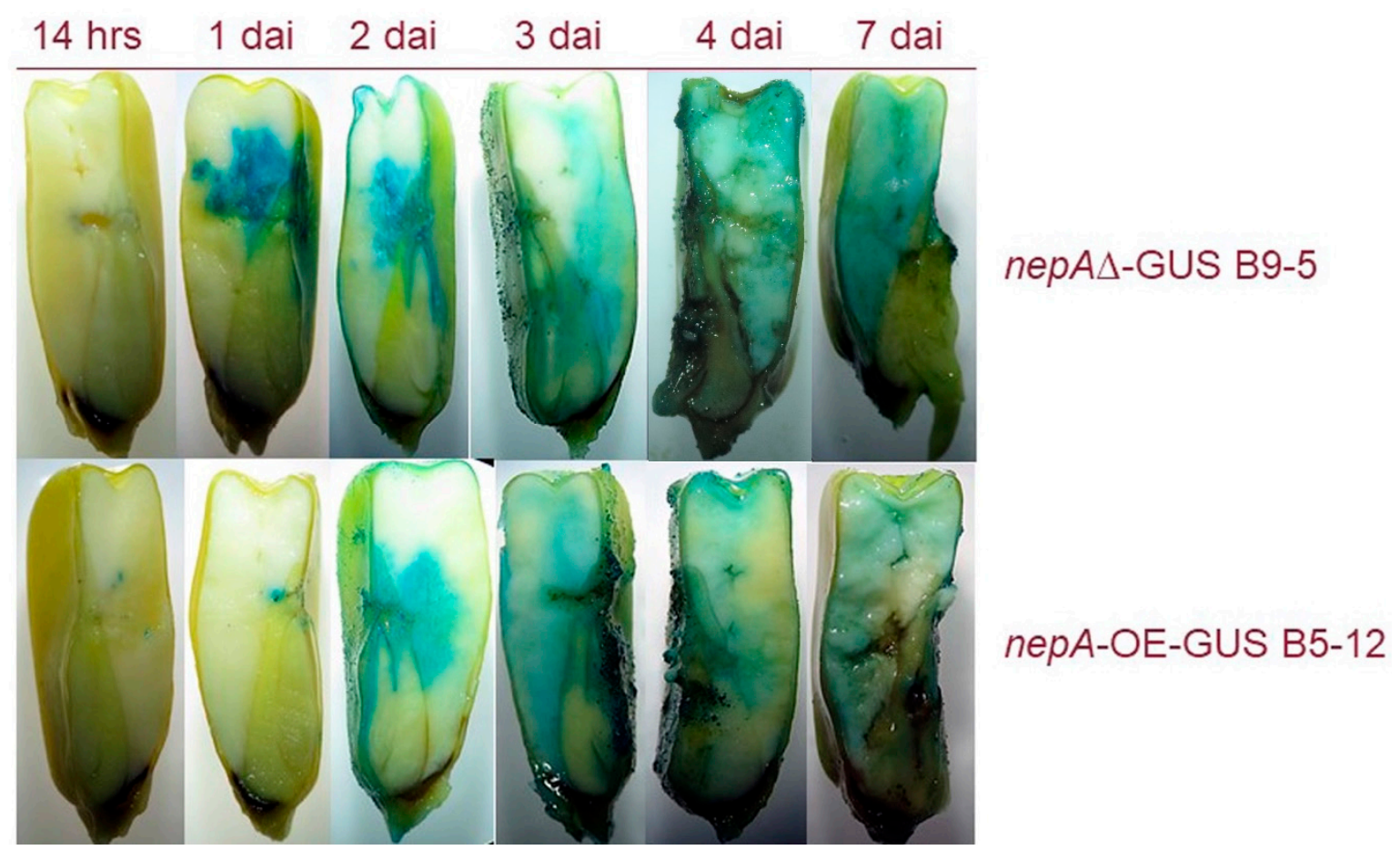

Figure 5. Histochemical assay for nepAD-GUS B9-5 and for nepA-OE-GUS B5-12 strains. Timeline follows infection process starting from the pericarp and the endosperm to the embryo region.

\section{Materials and methods}

\subsection{Aspergillus flavus Strains}

The A. flavus used in this study is the aflatoxin-producer wild-type strain AF3357 [38] and five mutants (Table 1): (i) AFC-1 is a double auxotroph mutant lacking $p y r G$ and $\arg D$ gene thus requires arginine and uracil to be supplemented in growth media [16]. Mutant strains (ii) $\mathrm{Zn}_{2} \mathrm{Cys}_{6} \Delta$ and (iii) $\mathrm{Zn}_{2} \mathrm{Cys}_{6} \triangle-O E$-GFP were generated during this study: both derived from AFC-1 and are auxotrophic for uracil but in the $Z_{2} n_{2} C y s_{6} \Delta$ strain the transcription factor $Z n_{2} C y s_{6}$ is deleted while in the $\mathrm{Zn}_{2} \mathrm{Cys}_{6} \Delta$-OE-GFP strain the same gene is instead over-expressed (protocol in Section 3.2 below). Concerning the other two mutants, one strain presents the (iv) nepA gene deletion (nepA $\triangle$-GUS 
B9-5) while, in the other (v) nepA is overexpressed (nepA-OE-GUS B5-12; Gary Payne, not published). The strains first had to be cultured on media $\left(30{ }^{\circ} \mathrm{C}\right.$ for 7 days) to create spore suspensions that would be used to inoculate maize kernels. Most of the strains were cultured on Czapek Dox Broth or Agar (Difco), with the mutant strains requiring amendments to the medium of Uracil $\left(\mathrm{Zn}_{2} \mathrm{Cys}_{6} \Delta\right.$ and $\mathrm{Zn}_{2} \mathrm{Cys}_{6} \Delta-O E-G F P$ ) or Uracil and Arginine (AFC-1). The nepA mutants were grown on potato dextrose agar medium. All spore suspensions were diluted to a concentration of $1 \times 10^{6}$ spores $/ \mathrm{mL}$ in sterile distilled water amended with Triton X-100 (0.01\%). All the strains, except for the $Z_{2} n_{2}{ } s_{6} \Delta$ and $\mathrm{Zn}_{2} \mathrm{Cys}_{6}-\mathrm{OE}-\mathrm{GFP}$ mutants, were kindly provided by the laboratory of Professor G.A. Payne (CIFR, North Carolina State University, Raleigh, NC, USA). To facilitate infection, kernels were inoculated with a pin bar wetted with a solution of fungi spores $\left(1 \times 10^{6}\right.$ spores $\left./ \mathrm{mL}\right)$ incubated at $30^{\circ} \mathrm{C}$ for various time points and collected based on the protocol used [38]. For each strain, six kernels were inoculated as biological replicates and experiments were at least conducted twice.

Table 1. A. flavus strains.

\begin{tabular}{|c|c|c|c|}
\hline Strain & Growth Medium & Characteristics & References \\
\hline Aspergillus flavus 3357 & $\begin{array}{l}\text { Czapek Dox Broth or } \\
\text { Agar (CD, Difco) }\end{array}$ & Wild type & $\begin{array}{c}\text { Payne et al. (2007) } \\
\text { NRRL [39] }\end{array}$ \\
\hline AFC-1 & $\begin{array}{c}\text { Czapek Dox Broth or } \\
\text { Agar (CD, Difco) with } \\
\text { Uracil } 1.122 \mathrm{~g} / \mathrm{L} \text { and } 0.26 \\
\text { g/L of Arginine }\end{array}$ & $\begin{array}{c}\text { Mutant }(-p y r G,-\arg D) \\
\text { requires uracil and } \\
\text { arginine }\end{array}$ & $\begin{array}{l}\text { Georgianna et al. } \\
\text { (2010) [16] }\end{array}$ \\
\hline $\mathrm{Zn}_{2} \mathrm{Cys}_{6} \Delta$ & $\begin{array}{l}\text { Czapek Dox Broth or } \\
\text { Agar (CD, Difco) with } \\
\text { Uracil } 1.122 \mathrm{~g} / \mathrm{L}\end{array}$ & $\begin{array}{l}\text { auxotroph for uracil in } \\
\text { which the transcription } \\
\text { factor } Z n_{2} C y s_{6} \text { has been } \\
\text { deleted; it derives from } \\
\text { AFC-1 strain with } \\
\text { arginine auxotrophy } \\
\text { restored }\end{array}$ & This study \\
\hline $\mathrm{Zn}_{2} \mathrm{Cys}_{6}-\mathrm{OE-GFP}$ & $\begin{array}{l}\text { Czapek Dox Broth or } \\
\text { Agar (CD, Difco) with } \\
\text { Uracil } 1.122 \mathrm{~g} / \mathrm{L}\end{array}$ & $\begin{array}{l}\text { auxotroph for uracil in } \\
\text { which the transcription } \\
\text { factor } \mathrm{Zn}_{2} \mathrm{Cys}_{6} \text { is } \\
\text { overexpressed; it derives } \\
\text { from AFC- } 1 \text { strain with } \\
\text { arginine auxotrophy } \\
\text { restored }\end{array}$ & This study \\
\hline nepA-OE-GUS B5-12 & $\begin{array}{l}\text { Potato Dextrose Agar } \\
\text { (PDA, Difco) }\end{array}$ & $\begin{array}{c}\text { nерA gene } \\
\text { over-expressing strain }\end{array}$ & $\begin{array}{c}\text { G.A. Payne } \\
\text { (not published) }\end{array}$ \\
\hline 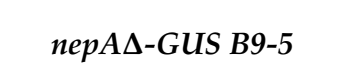 & $\begin{array}{l}\text { Potato Dextrose Agar } \\
\text { (PDA, Difco) }\end{array}$ & $\begin{array}{l}\text { nepA gene knock-out } \\
\text { strain }\end{array}$ & $\begin{array}{c}\text { G.A. Payne } \\
\text { (not published) }\end{array}$ \\
\hline
\end{tabular}

\subsection{Generation of $\mathrm{Zn}_{2} \mathrm{Cys}_{6} \Delta$ and $\mathrm{Zn}_{2} \mathrm{Cys}_{6}-\mathrm{OE}-\mathrm{GFP}$ Strains}

Gene deletion strategies of the transcription factor, $\mathrm{Zn}_{2} \mathrm{Cys}_{6}$, were performed through the restoration of auxotrophy in the AFC-1 strain. The $\mathrm{Zn}_{2} \mathrm{Cys}_{6} \Delta$ deletion construct was assembled combining three fragments: $\sim 1.5 \mathrm{~kb}$ regions upstream (5' UTR, $1542 \mathrm{bp}$ ) and downstream ( $3^{\prime}$ UTR, $1475 \mathrm{bp}$ ) of the $\mathrm{Zn}_{2} \mathrm{Cys}_{6}$ coding sequence were used as promoter and terminator to regulate the expression of the $\arg D$ marker gene $(2225 \mathrm{bp})$, which encodes for the acetyl ornithine aminotransferase. Each fragment was flanked with specific restriction sites suitably designed adjacent to the primers and added to the amplicons after PCR amplification (Table S6). The restriction enzymes used for cloning [AscI, FesI, Sbf-HF, PacI (NEB, Ipswich, MA, USA)] belong to the family of eight-base cutters whose special feature is the recognition of $8 \mathrm{bp}$ restriction sequences that rarely occur in a genome, which significantly increases their specificity. Fragments were individually cloned into TOPO vector pCR 2.1 (TOPO ${ }^{\circledR}$ CLONING KIT, Invitrogen, Carlsberg, CA, USA) and then used to transform 
One Shot ${ }^{\circledR}$ Top10 competent cells. This procedure was performed according to the manufacturer's instruction. Plasmids were extracted using a MINI PREP KIT (Merck KGaA, Darmstadt, Germany) and checked through PCR (Table S6) to assess for the correct insertions. The assembly of the construct started with the double digestion of the vectors harbouring $\arg D$ and $5^{\prime}$ UTR using enzymes AscI and FseI; the reactions occurred over night at $37^{\circ} \mathrm{C}$. After, the excised $5^{\prime}$ UTR fragment and the linearised plasmid containing $\arg D$ were separated by gel electrophoresis, purified using GenElute Gel Extraction Kit (Merck KGaA, Darmstadt, Germany) and quantified. Suitable amounts of the $5^{\prime}$ UTR fragment and the linearized plasmid harbouring $\arg D$ gene were incubated over night at RT with T4 DNA Ligase (Promega, Madison, WIS, USA) with the aim of obtaining a single vector with $5^{\prime}$ UTR fused to the marker. This plasmid was then used to transform Top10 cells by thermal shock and 10 colonies, randomly selected on Luria-Bertani (LB) supplemented with $100 \mu \mathrm{g} / \mathrm{mL}$ of ampicillin, were grown for plasmid recovery. The correct assembly was checked by PCR (Table S6). A similar methodology was adopted for the second part of the assembly in which the fusion of $3^{\prime}$ UTR and $5^{\prime}$ UTR+argD was determined. $3^{\prime}$ UTR and $5^{\prime}$ UTR $+\arg D$ were individually double-digested using restriction enzymes SbfI-HF and PacI (NEB, Ipswich, MA, USA). The excised 3' UTR fragment and the linearised plasmid containing $5^{\prime}$ UTR $+\arg D$ were separated by gel electrophoresis, purified and quantified. The vector harbouring $5^{\prime}$ UTR $+\arg D$ was then incubated (overnight at RT) with linear $3^{\prime}$ UTR and T4 DNA Ligase (Promega, Madison, WIS, USA). Thus, the obtained plasmid was used to transform Top10 cells and plated onto LB + Amp $100 \mu \mathrm{g} / \mathrm{mL}$. Randomly selected colonies were grown over night in LB medium for plasmid recovery. Digestion using EcoRI and PCR amplification were performed to assess the correct assembly of the entire gene-deletion construct.

The $\mathrm{Zn}_{2} \mathrm{Cys}_{6}$-OE-GFP strain was obtained by transformation of the auxotrophic mutant AFC-1 strain (-pyrG; - $\operatorname{argD}$ ). The $\mathrm{Zn}_{2} \mathrm{Cys}_{6}-\mathrm{OE}-\mathrm{GFP}$ construct was generated by cloning $\mathrm{Zn}_{2} \mathrm{Cys}_{6}$ gene, placed under the control of the cytomegalovirus (CMV) promoter and fused to green fluorescent protein (GFP), into the pNuc'EM2 plasmid [40]. $\mathrm{Zn}_{2} \mathrm{Cys}_{6}$ was PCR amplified from A. flavus NRRL genomic DNA (primers reported in Table S6) to which sequences containing restriction sites recognized by HindIII and KpnI enzymes (NEB, Ipswich, MA, USA) were added. The PCR-amplified fragment was purified, cloned into plasmid TOPO vector pCR 2.1 with TOPO ${ }^{\circledR}$ CLONING KIT (Invitrogen, Carlsberg, CA, USA) and used to transform One Shot ${ }^{\circledR}$ Top10 chemically competent $E$. coli. The correct insertion of the gene was checked by PCR after plasmid recovery (Table S6). With the aim to excise the $\mathrm{Zn}_{2} \mathrm{Cys}_{6}$ fragment from $\mathrm{pCR} 2.1$ vector and to clone into $\mathrm{pNuc}$ 'EM2, two individual double digestions of pCR $2.1+\mathrm{Zn}_{2} \mathrm{Cys}_{6}$ and pNuc'Em2 plasmid were performed using HindIII and KpnI enzymes $\left(37^{\circ} \mathrm{C}\right.$ for $1.5 \mathrm{~h}$ ). The excised $\mathrm{Zn}_{2} \mathrm{Cys}_{6}$ and the linearised pNuc'EM2 vector were gel purified with a GenElute Gel Extraction Kit (Sigma, St. Louis, MO, USA). After a ligation step (T4 DNA Ligase, Promega, Madison, WIS, USA), the desired plasmid was used to transform competent Top10 cells and was recovered with a GenElute Plasmid Miniprep Kit (Sigma, St. Louis, MO, USA). Primers CMV_Fw/GFP_Rev were used to test the correct assembly of the CMV-Zn ${ }_{2} \mathrm{Cys}_{6}$-GFP construct (Table S6). Transformation of AFC-1 strain was performed with the aim to obtain all the desired mutants: the linearised plasmid harbouring $5^{\prime}$ UTR-argD-3' UTR was used for the deletion mutant $\mathrm{Zn}_{2} \mathrm{Cys}_{6} \Delta$, while the overexpression construct $\mathrm{Zn}_{2} \mathrm{Cys}_{6}$-OE-GFP and the $\arg \mathrm{D}$ gene were used to co-transform the AFC-1 strain for the overexpression mutant. All the transformations were performed as reported by He et al. [41]. Transformants were selected on Czapek Dox Agar media plus Uracil after $2-4$ days of incubation at $37^{\circ} \mathrm{C}$.

\subsection{Zea Mays Crops}

The kernels used was Pioneer P1543 FAO class 600 from 130 days, kindly provided by Agricola $2000 \mathrm{srl}$ (Milano, Italy). Maize kernels were surface sterilised with two 5-min washes of $80 \%$ ethanol, followed by two 15 -min washes with $50 \%$ bleach and five rinses with sterile distilled water. Sterilisation was considered necessary to remove environmental residues that could have altered the experiment. 


\subsection{Gene Expression Analysis}

Total RNA was extracted using a Trizol (Invitrogen, Carlsbad, CA, USA) based protocol with only sterilised material with Diethyl pyrocarbonate (DEPC). RNA was quantified with Qubit RNA Assay kit (Life Technologies, Carlsbad, CA, USA) or Nanodrop (Thermo Scientific, Waltham, MA, USA). To remove DNA contamination, RNA was digested with DNAseI (Promega, Madison, WIS, USA) and complementary DNA (cDNA) was obtained by retro-transcription of $1 \mu \mathrm{g}$ of RNA using SensyFAST cDNA synthesis kit (Bioline, London, UK). The cDNA was subjected to quantitative analysis of the expression profile for each gene of interest: $\mathrm{SalOH}$ (salicylate hydroxylase), npp1 (necrosis- and ethylene-inducing peptide) and AFLA_096026 (aromatic, ring-opening dioxygenase family protein). Gene expression in our $A$. flavus strains was compared to a housekeeping gene ( $\beta$-tub, AFLA_068620) using a qRT-PCR (see Table S7 for primers). Three technical replicates were used for RT-qPCR.

\subsection{Rutin Degradation}

With the aim to assess rutin degradation, A. flavus strain AF3357 was maintained on Czapek Dox Agar, amended with $\mathrm{ZnSO}_{4}(5 \mathrm{mg} / \mathrm{L})$ and $\mathrm{NaMoO}_{4}(1 \mathrm{mg} / \mathrm{L})$ at $30^{\circ} \mathrm{C}$. Seven days later the spores were suspended in 5-6 mL of sterile distilled water and Triton X-100 (0.01\%, Sigma St. Louis, MO, USA) and inoculated into $100 \mathrm{~mL}$ of Potato Dextrose Broth $\left(1 \times 10^{5}\right.$ spores $\left./ \mathrm{mL}\right)$ and grown at $28{ }^{\circ} \mathrm{C}$ for 7 days in static. Concomitantly, AF3357 was used to inoculate $100 \mathrm{~mL}$ of Potato Dextrose Broth containing rutin $0.02 \mathrm{mg} / \mathrm{mL}$ [34]. Culture filtrates were sampled at seven different time intervals from 0 up to $168 \mathrm{~h}$ post inoculation (hpi). Then, $2 \mathrm{~mL}$ of ethyl acetate were added to $2 \mathrm{~mL}$ of culture filtrate add the internal reference standard (chlorogenic acid, SIGMA, St. Louis, MO, USA) at a final concentration of $10 \mu \mathrm{M}$. The samples were evaporated to dryness, re-suspended in $200 \mu \mathrm{L}$ of methanol and finally filtered with a Millex-HV $0.45 \mu \mathrm{m}$ filter from Millipore (Merck Millipore, Bedford, CA, USA) before HPLC-MS/MS analysis reported below.

\subsection{Salicylic Acid, Catechol, Rutin, Quercetin and Aflatoxin B1 Analysis by HPLC-MS/MS}

Maize kernels were infected with AF3357, AFC-1, $\mathrm{Zn}_{2} \mathrm{Cys}_{6}-\mathrm{OE}-\mathrm{GFP}$ to compare the relative quantity of SA and its by-product catechol. Infected and not infected kernel were freeze-dried and grounded in presence of liquid nitrogen. The extraction and the analysis were performed following the hormone method extraction reported in Scala et al. [42] with some modification. Thirty $\mathrm{mg}$ were extracted with $750 \mu \mathrm{L} \mathrm{MeOH}-\mathrm{H}_{2} \mathrm{O}-\mathrm{HOAc}(90: 9: 1, v / v / v)$ in presence of the internal standard 1-Naphthaleneacetic acid (NAA MW $186.21 \mathrm{~g} \cdot \mathrm{mol}^{-1}$ ) at $5 \mu \mathrm{M}$ final concentration. Extraction was repeated and the supernatant was collected and dried by nitrogen flow. Extract was resuspended in $200 \mu \mathrm{L}$ of $0.05 \%$ HOAc in $\mathrm{H}_{2} \mathrm{O}-\mathrm{MeCN}(85: 15, v / v)$. Analysis was conducted by HPLC-MS/MS Agilent 6420 (Agilent Technologies, Santa Clara, CA, USA). Chromatographic separation was performed with a Zorbax ECLIPSE XDB-C18 rapid resolution HT $4.6 \times 50 \mathrm{~mm} 1.8 \mu \mathrm{m}$ p.s. column (Agilent Technologies, Santa Clara, CA, USA) at room temperature, and the injected volume was $10 \mu \mathrm{L}$.

The acquisition was in MRM negative ion mode $[\mathrm{M}-\mathrm{H}]^{-}$for SA and cathecol. The mobile phases consisted of $\mathrm{A}: \mathrm{H}_{2} \mathrm{O}$ containing $0.05 \% \mathrm{HOAc}$, and B: Acetonitrile at a constant flow-rate of $600 \mathrm{~mL} \cdot \mathrm{min}^{-1}$. The elution gradient was as follows: $0-3 \mathrm{~min} 15 \% \mathrm{~B}, 3-5 \min 100 \% \mathrm{~B}, 5-6 \mathrm{~min} 100 \% \mathrm{~B}$, $6-7 \min 15 \%$ B, $7-8 \min 15 \%$ B. The gradient was followed by a 5 min re-equilibration. For aflatoxin B1, the acquisition was in MRM positive ion mode $[\mathrm{M}+\mathrm{H}]^{+}$. Chromatographic separation was performed with a Zorbax Eclipse XDB-C18, $50 \times 4.6 \mathrm{~mm}$ inner diameter, $1.8 \mu \mathrm{m}$ particle size, (Agilent Technologies, Santa Clara, CA, USA) at $25^{\circ} \mathrm{C}$ and the injection volume was $5 \mu \mathrm{L}$. The mobile phases consisted of A: methanol/water/acetic acid 10:89:1 (v/v/v) and B: methanol/water/acetic acid 97:2:1 (v/v/v) while both contained $5 \mathrm{mM}$ ammonium acetate. The total runtime was $20 \mathrm{~min}$, with a flow rate of $0.4 \mathrm{~mL} / \mathrm{min}$. The gradient elution was as follows: $0-2 \min 1 \%$ B, 3-14 $\min 99 \%$ B, 15-18 $\min 99 \%$ B, $19-20$ min 1\% B. The gradient was followed by $4 \mathrm{~min}$ for re-equilibration. 
For rutin and quercetin, the acquisition was in MRM positive ion mode $[\mathrm{M}-\mathrm{H}]^{+}$. The elution gradient was carried out with binary solvent system consisting of $5 \mathrm{mM} \mathrm{NH}_{4} \mathrm{AcO}$ in $\mathrm{H}_{2} \mathrm{O}$ (solvent $\mathrm{A}$ ) and $5 \mathrm{mM} \mathrm{NH}_{4} \mathrm{AcO}$ in $\mathrm{MeOH}$ (solvent $\mathrm{B}$ ) at a constant flow-rate of $600 \mathrm{~mL} \cdot \mathrm{min}^{-1}$. The elution gradient was as follows: $0-2 \min 0 \% \mathrm{~B}, 0-14 \mathrm{~min} 100 \% \mathrm{~B}, 14-18 \mathrm{~min} 100 \% \mathrm{~B}$, with $2 \mathrm{~min}$ for re-equilibration. The MRM fragmentation patterns for each compound are listed in Table 2. The values for rutin and quercetin provided as relative abundance are reported in Table S5.

Table 2. MRM parameters.

\begin{tabular}{cccccc}
\hline Compound & Precursor Ion & Product Ion & Fragmentor (V) & CE (eV) & Polarity \\
\hline SA & 137.2 & $92.9,64.8$ & 135 & 20 & {$[\mathrm{M}-\mathrm{H}]^{-}$} \\
\hline Catechol & 109.1 & 53.1 & 135 & 20 & {$[\mathrm{M}-\mathrm{H}]^{-}$} \\
\hline NAA & 245 & 180.8 & 100 & 16 & {$[\mathrm{M}-\mathrm{H}]^{-}$} \\
\hline Quercetin & 303.1 & 152.9 & 100 & 37 & {$[\mathrm{M}-\mathrm{H}]^{+}$} \\
\hline PPA & 291.3 & $129.1,112.8$ & 90 & 38 & {$[\mathrm{M}-\mathrm{H}]^{+}$} \\
\hline Chlorogenic acid & 353.31 & 191.2 & 135 & 10 & {$[\mathrm{M}-\mathrm{H}]^{-}$} \\
\hline Rutin & 609.2 & 273.1 & 100 & 56 & {$[\mathrm{M}-\mathrm{H}]^{-}$} \\
\hline Aflatoxin B1 & 313.1 & 241.1 & 135 & 38 & {$[\mathrm{M}-\mathrm{H}]^{+}$} \\
\hline
\end{tabular}

\subsection{Histological Protocol}

Maize kernels (infected and non-infected) were immersed in $70 \%$ ethanol for two hours, then $90 \%$ ethanol for two hours and next $100 \%$ ethanol overnight. Two hours in resin (Technovit ${ }^{\circledR} 7100-$ Haraeus-Kulzer, Wehrheim, Germany)/absolute ethanol (1/3), two hours in resin/absolute ethanol $(1 / 1)$, and two hours in resin/ absolute ethanol (3/1). Overnight impregnation (resin plus catalyst 1 ) was performed at $4{ }^{\circ} \mathrm{C}$ and then replaced with resin plus catalyst 2 (20:1) at room temperature for resin inclusion. The included samples were then cut with an automatic microtome HM 350 (Zeiss, Oberkochen, Germany) to $8 \mathrm{~mm}$ as thickness and stained with toluidine blue for $2 \mathrm{~min}$.

\subsection{Histochemical Assay}

Maize kernels (infected and non-infected) were transferred in cooled $\left(-20{ }^{\circ} \mathrm{C}\right) 80 \%$ acetone (dilution with distilled water) and chilled for $20 \mathrm{~min}$ at $-20^{\circ} \mathrm{C}$. Acetone was removed and samples were washed three times with distilled water before the addition of GUS buffer to the samples. An infiltration of $15 \mathrm{~min}$ under vacuum was performed, followed by incubation at $37^{\circ} \mathrm{C}$ in darkness for at least $2 \mathrm{~h}$. To fix the reaction, the GUS buffer was removed, then replaced with $70 \%$ ethanol and preserved at $4{ }^{\circ} \mathrm{C}$. The time points of withdrawals were $4 \mathrm{~h}, 8 \mathrm{~h}, 16 \mathrm{~h}, 24 \mathrm{~h}, 48 \mathrm{~h}, 72 \mathrm{~h}, 96 \mathrm{~h}$ and $7 \mathrm{~d}$. No histochemical data is available for the 4 and $8 \mathrm{~h}$ time points because $A$. flavus growth was not detectable. The microscopic observation was carried out with objective $40 \times$.

\subsection{TUNEL Assay}

Programmed cell death was evaluated using terminal deoxynucleotidyl transferase (TdT)-mediated dUTP nick-end labelling (TUNEL assay) using a TACS $\mathrm{XL}^{\mathrm{TM}}$ detection kit (R\&D Systems, Minneapolis, MN, USA). Procedures were performed according to the manufacturer's instructions on kernel sections (6 $\mu \mathrm{m}$ thick) immediately observed under a light microscope (Leica DMRB), and photographs were captured using a by DC500 (Leica, Wetzlar, Germany). Both positive and negative controls were performed according to the manufacturer. The microscopic observation was carried out with objective $100 \times$. 


\section{Conclusions}

In general, the biosynthesis of secondary metabolites has not been studied to the same extent of that of primary metabolites. Nevertheless, due to the economic importance of many secondary metabolites, they have more and more been the focus of many research efforts [43-45]. The aflatoxin biosynthetic pathway has been well-characterized by several works [5]; yet, information about the regulatory mechanisms is still partial [38,39]. A previous transcriptional analysis on 56 individual secondary metabolite clusters within the genome of $A$. flavus [17] showed a significative patterns of up-regulation, during maize kernel infection. Within this pattern, cluster 32 was especially interesting because it includes two genes involved in the synthesis of Aflatrem, a potent tremorgenic mycotoxin linked to neurological disorders [18]. The objective of the present work was to characterize the role of the genes within cluster 32 which are involved in the early stages of the infection process. Aflatoxin B1 synthesis is not apparently affected by deletion or overexpression of the transcription factor putatively controlling this cluster, even if an intriguingly - not statistically significant-downregulation emerged in the $\mathrm{Zn}_{2} \mathrm{Cys}_{6} \Delta$ strain (compared to AF3357; T test $p=0.09$ ) (Table S8). During the first phase of infection (from 2 and 4 dai), we monitored $A$. flavus colonisation of maize kernels by observing histological sections with an optical microscope. As shown in Figure 1, the pathogenic process starts from the external layers and progresses through the aleuronic layer towards the embryo. Our results suggest that $A$. flavus mainly overcomes plant defences in the aleuronic layer to induce PCD in the kernel. This hypothesis is validated by the TUNEL assay, where the presence of apoptotic nuclei becomes evident (Figure 2). In our experimental design, we also included $A$. flavus mutant strains (Table 1, Section 3): data show that AFC-1, auxotroph for arginine and uracil, has a delayed infection onset, while $\mathrm{Zn}_{2} \mathrm{Cys}_{6}$-OE-GFP, overexpressing cluster 32, performs similarly to A. flavus 3357 . To better characterize cluster 32 centrality to the infection process, we looked at the transcriptional levels of three genes within cluster 32: salicylate hydroxylase $(\mathrm{SalOH})$, the necrosis and ethylene inducing protein (npp1), and quercetin dehydrogenase (AFLA_096260). The elected genes are shown to enable infection by preventing effective plant defence (Figure 3). $\mathrm{Zn}_{2} \mathrm{Cys}_{6}-\mathrm{OE}-\mathrm{GFP}$, the strain overexpressing the transcription factor $\mathrm{Zn}_{2} \mathrm{Cys}_{6}$, shows related transcription levels higher than AF 3357 which correlate to a heightened virulence, arguably due to cluster 32 upregulation.

The activity of $\mathrm{SalOH}$ (converting the salicylic acid in cathecol) was validated also by HPLC/MS-MS. We observed an increased level of cathecol in comparison to the starting level of salicylic acid in all A. flavus strains (Figure 4). This evidence corroborates the centrality of cluster 32 in the infection process, since $A$. flavus is able to bypass the plant defences, namely those regulated by SA, by taking advantage of the activity of genes specifically encoded by cluster 32. NLPs are non-specific toxins capable of inducing host tissue necrosis and defence responses [30]. We provide evidence in this sense by showing that npp1 is involved in $A$. flavus virulence on maize kernels. Experiments on two strains, nepA-OE-GUS B5-12 and nepAD-GUS B9-5, allowed us to show induced necrotrophy through histochemical assays (Figure 5). The infection starts from the aleuronic layer, which represents the barrier between the plant and the fungus. Maize colonisation by nepA $\Delta$-GUS B9-5 is similar to colonisation by nepA-OE-GUS $B 5-12$, which supports the idea that reduced pathogenicity of the nepAD-GUS B9-5 strain is not the direct consequence of a decreased growth rate, and suggest a central role of $n p p 1$ in the inter process that sees the saprophytic lifestyle of $A$. flavus.

In $A$. flavus-maize competition, cluster 32 appears to represent the "winning hand" of the pathogen over the host and, by extension, the genetic element that enables the lifestyle switch from biotrophic to necrotrophic. We can thus argue that cluster 32 has acquired a centrality in A. flavus ecology, which makes it an interesting topic in future research efforts, especially those aimed at providing the host plant with genetic elements to confer innate resistance.

Supplementary Materials: Supplementary materials can be found at http://www.mdpi.com/1422-0067/21/21/ 8213/s1. 
Author Contributions: Conceptualization: M.R.; methodology: S.R.L.S., S.D., X.S., G.O.; software: L.A., S.R.L.S., M.B.; validation: M.R., S.R.L.S.; formal analysis: L.A., M.B.; investigation: M.R., L.A., S.D., C.M., G.O., X.S., S.R.L.S.; resources: M.R.; supervision: M.R., V.S., G.A.P.; data curation: L.A., S.R.L.S., M.B.; writing-original draft preparation: L.A.; writing—review and editing: M.R., M.B., V.S., M.Z., G.A.P.; project administration: M.R.; Funding acquisition: M.R. All authors have read and agreed to the published version of the manuscript.

Funding: This research received no external funding.

Acknowledgments: The authors thank the Sapienza University for providing laboratory space.

Conflicts of Interest: The authors declare no conflict of interest.

\section{Abbreviations}

$\begin{array}{ll}\text { AF } & \text { Aflatoxin } \\ \text { dai } & \text { Day After Inoculation } \\ \text { EFSA } & \text { European Food Safety Authority } \\ \text { GUS } & \text { ß-Glucuronidase } \\ \text { HR } & \text { Hypersensitive Response } \\ \text { PCD } & \text { Programmed Cell Death } \\ \text { PPA } & \text { protocatechuoyl-phloroglucinolcarboxylic acid } \\ \text { ROS } & \text { Reactive Oxygen Species } \\ \text { SA } & \text { Salicylic Acid } \\ \text { SM } & \text { Secondary Metabolites } \\ \text { SMURF } & \text { Secondary Metabolite Unknown Regions Finder } \\ \text { TUNEL } & \text { Terminal Deoxynucleotidyl Transferase dUTP Nick end Labeling }\end{array}$

\section{References}

1. Amaike, S.; Keller, N.P. Aspergillus flavus. Annu. Rev. Phytopathol. 2011, 49, 107-133. [CrossRef] [PubMed]

2. Hedayati, M.T.; Pasqualotto, A.C.; Warn, P.A.; Bowyer, P.; Denning, D.W. Aspergillus flavus: Human pathogen, allergen and mycotoxin producer. Microbiology 2007, 153, 1677-1692. [CrossRef] [PubMed]

3. Horn, B.W. Biodiversity of Aspergillus section Flavi in the United States: A review. Food Addit. Contam. 2007, 24, 1088-1101. [CrossRef] [PubMed]

4. Dowd, P.F. Involvement of Arthropods in the Establishment of Mycotoxigenic Fungi under Field Conditions; Marcel Dekker: New York, NY, USA, 1998.

5. Payne, G.A.; Brown, M.P. Genetics and physiology of aflatoxin biosynthesis. Annu. Rev. Phytopathol. 1998, 36, 329-362. [CrossRef] [PubMed]

6. Guo, B.Z.; Butrón, A.; Li, H.; Widstrom, N.W.; Lynch, R.E. Restriction fragment length polymorphism assessment of the heterogeneous nature of maize population GT-MAS: Gk and field evaluation of resistance to aflatoxin production by Aspergillus flavus. J. Food Prot. 2002, 65, 167-171. [CrossRef] [PubMed]

7. Raruang, Y.; Omolehin, O.; Hu, D.; Wei, Q.; Han, Z.-Q.; Rajasekaran, K.; Cary, J.W.; Wang, K.; Chen, Z.Y. Host induced gene silencing targeting Aspergillus flavus aflM reduced aflatoxin contamination in transgenic maize under field conditions. Front. Microbiol. 2020, 11, 754. [CrossRef]

8. Gorman, D.P.; Kang, M.S. Preharvest Aflatoxin Contamination in Maize: Resistance and Genetics. Plant Breed. 1991, 107, 1-10. [CrossRef]

9. EFSA Panel on Contaminants in the Food Chain (CONTAM); Schrenk, D.; Bignami, M.; Bodin, L.; Chipman, J.K.; del Mazo, J.; Grasl-Kraupp, B.; Hogstrand, C.; Hoogenboom, L.; Leblanc, J.C.; et al. Risk assessment of aflatoxins in food. EFSA J. 2020, 18, e06040. [CrossRef]

10. Ehrlich, K.C. Non-aflatoxigenic Aspergillus flavus to prevent aflatoxin contamination in crops: Advantages and limitations. Front. Microbiol. 2014, 5, 50. [CrossRef] [PubMed]

11. Battilani, P.; Toscano, P.; Van der Fels-Klerx, H.J.; Moretti, A.; Leggieri, M.C.; Brera, C.; Rortais, A.; Goumperis, T.; Robinson, T. Aflatoxin B 1 contamination in maize in Europe increases due to climate change. Sci. Rep. 2016, 6, 24328. [CrossRef] [PubMed]

12. Calvo, A.M.; Cary, J.W. Association of fungal secondary metabolism and sclerotial biology. Front. Microbiol. 2015, 6, 62. [CrossRef] [PubMed] 
13. Soni, P.; Gangurde, S.S.; Ortega-Beltran, A.; Kumar, R.; Parmar, S.; Sudini, H.K.; Lei, Y.; Ni, X.; Huai, D.; Fountain, J.C. Functional Biology and Molecular Mechanisms of Host-Pathogen Interactions for Aflatoxin Contamination in Groundnut (Arachis hypogaea L.) and Maize (Zea mays L.). Front. Microbiol. 2020, 11. [CrossRef]

14. Keller, N.P.; Turner, G.; Bennett, J.W. Fungal secondary metabolism-From biochemistry to genomics. Nat. Rev. Microbiol. 2005, 3, 937-947. [CrossRef]

15. Khaldi, N.; Seifuddin, F.T.; Turner, G.; Haft, D.; Nierman, W.C.; Wolfe, K.H.; Fedorova, N.D. SMURF: Genomic mapping of fungal secondary metabolite clusters. Fungal Genet. Biol. 2010, 47, 736-741. [CrossRef]

16. Georgianna, D.R.; Fedorova, N.D.; Burroughs, J.L.; Dolezal, A.L.; Bok, J.W.; Horowitz-Brown, S.; Woloshuk, C.P.; Yu, J.; Keller, N.P.; Payne, G.A. Beyond aflatoxin: Four distinct expression patterns and functional roles associated with Aspergillus flavus secondary metabolism gene clusters. Mol. Plant Pathol. 2010, 11, 213-226. [CrossRef] [PubMed]

17. Reverberi, M.; Punelli, M.; Scala, V.; Scarpari, M.; Uva, P.; Mentzen, W.I.; Dolezal, A.L.; Woloshuk, C.; Pinzari, F.; Fabbri, A.A. Genotypic and phenotypic versatility of Aspergillus flavus during maize exploitation. PLoS ONE 2013, 8. [CrossRef]

18. Valdes, J.J.; Cameron, J.E.; Cole, R.J. Aflatrem: A tremorgenic mycotoxin with acute neurotoxic effects. Environ. Health Perspect. 1985, 62, 459-463. [CrossRef]

19. Ehrlich, K.C.; Mack, B.M. Comparison of expression of secondary metabolite biosynthesis cluster genes in Aspergillus flavus, A. parasiticus, and A. oryzae. Toxins (Basel) 2014, 6, 1916-1928. [CrossRef] [PubMed]

20. Keates, S.E.; Kostman, T.A.; Anderson, J.D.; Bailey, B.A. Altered gene expression in three plant species in response to treatment with Nep1, a fungal protein that causes necrosis. Plant Physiol. 2003, 132, 1610-1622. [CrossRef]

21. Staats, M.; van Baarlen, P.; Schouten, A.; van Kan, J.A.L. Functional analysis of NLP genes from Botrytis elliptica. Mol. Plant Pathol. 2007, 8, 209-214. [CrossRef]

22. Laluk, K.; Mengiste, T. Necrotroph attacks on plants: Wanton destruction or covert extortion? Arab. Book/Am. Soc. Plant Biol. 2010, 8. [CrossRef] [PubMed]

23. Ibarra, B.A.; Lohmar, J.M.; Satterlee, T.; McDonald, T.; Cary, J.W.; Calvo, A.M. The 14-3-3 protein homolog ArtA regulates development and secondary metabolism in the opportunistic plant pathogen Aspergillus flavus. Appl. Environ. Microbiol. 2018, 84, e02241-17. [CrossRef] [PubMed]

24. Chang, P.-K.; Ehrlich, K.C. Genome-wide analysis of the Zn (II) 2 Cys 6 zinc cluster-encoding gene family in Aspergillus flavus. Appl. Microbiol. Biotechnol. 2013, 97, 4289-4300. [CrossRef]

25. Nobili, C.; D'Angeli, S.; Altamura, M.M.; Scala, V.; Fabbri, A.A.; Reverberi, M.; Fanelli, C. ROS and 9-oxylipins are correlated with deoxynivalenol accumulation in the germinating caryopses of Triticum aestivum after Fusarium graminearum infection. Eur. J. Plant Pathol. 2014, 139, 429-444. [CrossRef]

26. Nayak, S.N.; Agarwal, G.; Pandey, M.K.; Sudini, H.K.; Jayale, A.S.; Purohit, S.; Desai, A.; Wan, L.; Guo, B.; Liao, B. Aspergillus flavus infection triggered immune responses and host-pathogen cross-talks in groundnut during in-vitro seed colonization. Sci. Rep. 2017, 7, 1-14. [CrossRef]

27. Qi, P.-F.; Zhang, Y.-Z.; Liu, C.-H.; Chen, Q.; Guo, Z.-R.; Wang, Y.; Xu, B.-J.; Jiang, Y.-F.; Zheng, T.; Gong, X. Functional analysis of FgNahG clarifies the contribution of salicylic acid to wheat (Triticum aestivum) resistance against Fusarium head blight. Toxins (Basel) 2019, 11, 59. [CrossRef]

28. Hao, G.; Naumann, T.A.; Vaughan, M.M.; McCormick, S.; Usgaard, T.; Kelly, A.; Ward, T.J. Characterization of a Fusarium graminearum Salicylate Hydroxylase. Front. Microbiol. 2019, 9, 3219. [CrossRef]

29. Zhou, B.-J.; Jia, P.-S.; Gao, F.; Guo, H.-S. Molecular characterization and functional analysis of a necrosis-and ethylene-inducing, protein-encoding gene family from Verticillium dahliae. Mol. Plant-Microbe Interact. 2012, 25, 964-975. [CrossRef] [PubMed]

30. Feng, B.-Z.; Zhu, X.-P.; Fu, L.; Lv, R.-F.; Storey, D.; Tooley, P.; Zhang, X.-G. Characterization of necrosis-inducing NLP proteins in Phytophthora capsici. BMC Plant Biol. 2014, 14, 126. [CrossRef]

31. Cobos, R.; Calvo-Peña, C.; Álvarez-Pérez, J.M.; Ibáñez, A.; Diez-Galán, A.; González-García, S.; García-Angulo, P.; Acebes, J.L.; Coque, J.J.R. Necrotic and cytolytic activity on grapevine leaves produced by Nep1-like proteins of Diplodia seriata. Front. Plant Sci. 2019, 10. [CrossRef]

32. Lattanzio, V.; Lattanzio, V.M.T.; Cardinali, A. Role of phenolics in the resistance mechanisms of plants against fungal pathogens and insects. Phytochem. Adv. Res. 2006, 661, 23-67. 
33. Tungmunnithum, D.; Thongboonyou, A.; Pholboon, A.; Yangsabai, A. Flavonoids and Other Phenolic Compounds from Medicinal Plants for Pharmaceutical and Medical Aspects: An Overview. Medicines (Basel Switz.) 2018, 5, 93. [CrossRef]

34. Chitarrini, G.; Nobili, C.; Pinzari, F.; Antonini, A.; De Rossi, P.; Del Fiore, A.; Procacci, S.; Tolaini, V.; Scala, V.; Scarpari, M. Buckwheat achenes antioxidant profile modulates Aspergillus flavus growth and aflatoxin production. Int. J. Food Microbiol. 2014, 189, 1-10. [CrossRef]

35. Asters, M.C.; Williams, W.P.; Perkins, A.D.; Mylroie, J.E.; Windham, G.L.; Shan, X. Relating significance and relations of differentially expressed genes in response to Aspergillus flavus infection in maize. Sci. Rep. 2014, 4, 4815. [CrossRef]

36. Keller, N.P.; Adams, T.H. Analysis of a mycotoxin gene cluster in Aspergillus nidulans. SAAS Bull. Biochem. Biotechnol. 1995, 8, 14-21.

37. Keller, N.P.; Butchko, R.A.E.; Sarr, B.; Phillips, T.D. A visual pattern of mycotoxin production in maize kernels by Aspergillus spp. Phytopathology 1994, 84, 483-488. [CrossRef]

38. Bhatnagar, D.; Ehrlich, K.C.; Cleveland, T.E. Molecular genetic analysis and regulation of aflatoxin biosynthesis. Appl. Microbiol. Biotechnol. 2003, 61, 83-93. [CrossRef]

39. Payne, G.A.; Yu, J.; Nierman, W.C.; Machida, M.; Bhatnagar, D.; Cleveland, T.E.; Dean, R.A. A First Glance into the Genome Sequence of Aspergillus fl avus. In The Aspergilli; CRC Press: Boca Raton, FL, USA, 2007; pp. 35-44.

40. Du, W.; Huang, Z.; Flaherty, J.E.; Wells, K.; Payne, G.A. Green fluorescent protein as a reporter to monitor gene expression and food colonization by Aspergillus flavus. Appl. Environ. Microbiol. 1999, 65, 834-836. [CrossRef]

41. He, Z.-M.; Price, M.S.; OBrian, G.R.; Georgianna, D.R.; Payne, G.A. Improved protocols for functional analysis in the pathogenic fungus Aspergillus flavus. BMC Microbiol. 2007, 7, 104. [CrossRef]

42. Scala, V.; Pietricola, C.; Farina, V.; Beccaccioli, M.; Zjalic, S.; Quaranta, F.; Fornara, M.; Zaccaria, M.; Momeni, B.; Reverberi, M. Tramesan Elicits Durum Wheat Defense against the Septoria Disease Complex. Biomolecules 2020, 10, 608. [CrossRef] [PubMed]

43. Fox, E.M.; Howlett, B.J. Secondary metabolism: Regulation and role in fungal biology. Curr. Opin. Microbiol. 2008, 11, 481-487. [CrossRef]

44. OBrian, G.R.; Fakhoury, A.M.; Payne, G.A. Identification of genes differentially expressed during aflatoxin biosynthesis in Aspergillus flavus and Aspergillus parasiticus. Fungal Genet. Biol. 2003, 39, 118-127. [CrossRef]

45. Caceres, I.; Khoury, A.A.; Khoury, R.E.; Lorber, S.; Oswald, I.P.; Khoury, A.E.; Atoui, A.; Puel, O.; Bailly, J.D. Aflatoxin Biosynthesis and Genetic Regulation: A Review. Toxins (Basel) 2020, 12, 150. [CrossRef] [PubMed]

Publisher's Note: MDPI stays neutral with regard to jurisdictional claims in published maps and institutional affiliations.

(C) 2020 by the authors. Licensee MDPI, Basel, Switzerland. This article is an open access article distributed under the terms and conditions of the Creative Commons Attribution (CC BY) license (http://creativecommons.org/licenses/by/4.0/). 